\title{
Empirical Review of the Impact of Fiscal Policy on the Manufacturing Sector of the Nigerian Economy (1980-2017)
}

\author{
ISRAEL ONOKERO IMIDE (PhD) \\ Nigeria Maritime University, Okerenkoko, Delta State, Nigeria
}

\begin{abstract}
The study examined Empirical Review of the Impact of Fiscal Policy on the Manufacturing sector of the Nigerian Economy from 1980 to 2017. The main objective of the study is to examine the impact of fiscal policy on the manufacturing sector of the Nigerian economy. The model for the study comprises of Index of Manufacturing Sector as endogenous variable and proxy by IMS and exogenous variables were; Government Expenditure (GEXP), Company Income Tax rate (CITR) and Federal Government Domestic debt Outstanding (FDDO). Annual time series data were gathered from the Central Bank of Nigeria Statistical Bulletins from 1980 to 2017. The techniques used for analysis are the Ordinary Least Square Techniques tested at the $5 \%$ level of significance. The econometric techniques of Ordinary Least Squares (OLS) results reveals that the Government Expenditure (GEX) and Company Income Tax Rate (CITR) have positive relationship with the Index of Manufacturing Sector (IMS) while Federal Government Domestic Debt Outstanding (FDDO) has negative linear relationship with the Index of Manufacturing Sector (IMS). The study concludes that Government Expenditure and Company Income Tax do not have significant impact on the manufacturing output, while the Federal Government Domestic Debt Outstanding showed a negative and statistically significant impact on the manufacturing sector. The study recommends amongst others that Government should channel its expenditure into the provision of direct physical structures that will be able to stand the competitive nature of both domestic and global markets as well as draw a policy plan that will subsidize company income tax for the manufacturing sub-sector rather than increase it.
\end{abstract}

Keywords: Fiscal Policy, Monetary Policy, Government Expenditure, Manufacturing sector, Nigeria Economy. DOI: $10.7176 / \mathrm{JESD} / 10-2-10$

\section{INTRODUCTION}

\subsection{Background to the Study}

There has been a growing concern over the role of fiscal policy on the impact on the manufacturing industry in the economic growth of Nigeria, despite the fact that the government had embarked on several policies aimed at improving the growth of Nigerian economy. Libanio (2006) through the use of Kaldor's first law defined manufacturing sector as the engine of growth of the economy.

Manufacturing involves the conversion of raw material into finished consumer goods or intermediate goods.

Manufacturing sector refers to those industries which are involved in the manufacturing and processing of items and indulge in either creation of new commodities or in value addition (Adebayo, 2010).

To Dickson( 2010), manufacturing sector accounts for a significant share of the industrial sector in developed countries. The final products can either serve as finished goods for sale to customers or as intermediate goods used in the production process.

Manufacturing sector as seen by (Loto, 2012) refers to an avenue for increasing productivity in relation to import replacement and export expansion, creating foreign exchange earning capacity, raising employment and per capital income which causes unrepeatable consumption pattern.

Mbele (2012) opined that manufacturing sector is involved in the process of adding value to raw materials by turning them into product.

Thus, manufacturing industries is the key variable in an economy and motivates conversion of raw material into finished goods.

Manufacturing industries create employment which helps to boost agriculture and diversify the economy while helping the nation to increase its foreign exchange earnings, and enabling local labour to acquire skills.

From the on-going, one can rightly say that, manufacturing is the process of transforming raw materials into usable forms either for direct consumption or further production.

The history of manufacturing in Nigeria can be traced to pre-colonial times. In village based societies of the Hausa, Bini and Yoruba among others, small scale manufacturing of goods for trade, social and other purposes prevailed.

The manufacturing industry in Nigeria is believed to be the main instrument of rapid growth, structural change and self-sufficiency. Therefore, it represents a major plank in government plan to restructure the economy and diversify its productive base (ukwu, 1994).

Though the high cost conditions in the country occasioned by poor and inadequate infrastructural support services and other policy induced costs pose a serious threat, not only for output growth in the manufacturing 
sector but also for competitiveness. Bogunijoko (2004) argued that the continued harassment of the companies by some state and local governments over unauthorized multiple levies and charges in spite of the clear position of the law, is a significant deviation from the characteristics requirement for a conducive business environment that the real sector needs to perform its role as the engine of growth.

The limitations imposed by infrastructural constraint due to outright shutdown of activities by local supplying industries, especially by state owned enterprises explain the less than expected performance in the manufacturing sector. Also, the drive to enhance local sourcing has continued to be constrained by inadequate technical facilities to process raw materials of the right technical specifications and quality including uncertainty of supplies arising from irregular production and supply schedules. The relative exorbitant process of some local raw materials compared with the imported counterparts occasioned essentially by high cost condition has compounded the problems of local sourcing of raw materials, Bogunijoko (2004).

The lack of a level ground for local industries to compete with cheap imports; owing to premature and uncoordinated pursuit of import liberalization, dumping and inconsistency in government policy has compounded the problem of unplanned inventories in the economy. The incidence of dumping and under invoicing of imports especially from Asian countries is threatening the survival of local industries.

While the best quality imports from advanced economies cut the fancy of the upper echelon of income group, those low priced substandard quality products from East Asian countries attracted the low income group whose purchasing power has been weakened by the massive depreciation of the naira value. This has not helped in improving the job creation posture of the government which is one of the critical success factors in ensuring a stable democracy.

Risikat .O (2016) observed that unemployment in Nigeria, which at the present is at an unacceptable level, poses a great threat to the political, economic and social stability of the nation, as crime, destitution, social exclusion and similar vices become prevalent. As a result of all these, the government has embarked upon various policies to address these issues.

The role of fiscal policy on the output and capacity utilization of the industry is inevitable. Fiscal policy drives the market for the manufacturing sector through the purposeful manipulation of government revenue and expenditure. When government is pursuing an expansionary policy, it reduces taxation and increases expenditure and the purchasing power of the economic unit which in turn expands the market for manufactured products. This in turn sends signal to the manufacturers to increase their productive capacity to take opportunity of the increase market demand. The reverse holds, when government pursues a contractionary fiscal policy.

The implementation of fiscal policy is especially routed through government budget.

Budget as a fiscal policy tool could be conceived as a structure that balances the changes in government revenue and expenditure over a period of time. It is a comprehensive financial plan, setting forth the expected route for achieving the financial and operational goals of a country (Meigs and Meigs, 2004). Literature regarding fiscal policy and economic growth can be discussed in two main streams. The first is the Neo Classical growth models of Solow (1956) and Swan (1956) which believed that, in the long run, it is the technological progress and population growth that determine economic growth. They are of the view that growth can influence some basic economic variables like; population growth rate, saving rate and index in human and physical capital investment through its different policies.

\subsection{Statement of the Problem}

Over the years, the performance of the manufacturing sector of the Nigerian economy has not been a satisfying one. From statistical reports, the contribution of the manufacturing sector to the growth of the Nigerian economy was relatively high in the period, 1966-75 at an annual average of 12.9 percent. This reflected the importance which the government attached to manufacturing activities and the adoption of import substitution, industrialization strategy which resulted in the establishment of many consumer goods industries, including soft drinks, cement, paints, soaps and detergents. Between 1976 and 1985, the growth rate in the sector expanded with the establishment of more import substitution industries with an annual average growth of 18.5 percent.

However, the collapse of the world crude oil market from the early 1980's drastically reduced foreign exchange earnings, and this negatively affected the sector that it could no longer able to import needed inputs. Hence, manufacturing output growth fell drastically to an annual average of about 2.6 percent during the period 1986-78 even with the introduction of SAP in 1986 up till 1993 growth in the sector was negative (Anyanwu, 2004).

From the work of Adebiy and Babatope Obasa (2004), it was found that the manufacturing sector in Nigeria has been experiencing a stunted growth and its contribution to gross domestic product has remained low. For instance, the manufacturing sector as a whole remains small, accounting for only 6.6 percent of GDP in 2006 and 12 percent of employment (World Bank,2008). The production indices also indicated that while agriculture and services experienced modest growth from103.5 and 101.5 to 133.6 and 297.0 between 2000 and 2001 respectively. Manufacturing sector recorded a decline from 109.492 .3 in the same period. It is also sad to 
mention that capacity utilization in the manufacturing sector declined from about 70.1 percent in 2000 to 44.3 in 2012 (CBN,2002) as cited by (Adebiyi \& Babatope- Obasa, 2004).

From statistical report, it has been observed that the contribution of manufacturing to GDP has not been encouraging in spite of the several policies put in place to encourage production for export. For instance, the manufacturing output in 1981 was 1558.70 \#billion and its contribution to GDP was 10.23 and capacity utilization was 73.3. In 2015, its contribution to GDP was 9.54 and capacity utilization was 59.9 percent (CBN, 2015) Statistical Bulletin

It is evident that manufacturing sub-sector of the Nigerian economy has not reached a desired stable level to perform its function as an engine of growth.

This shows that there is gross underutilization of resources. This might not be unconnected to factors such as poor macroeconomic performance of the economy, lack of adequate finance to purchase factory input, poor infrastructure and weak aggregate demand for manufactured exports, high price of products which is partly caused by high energy cost, inefficient and old equipment and poor infrastructure among others, Adejugbe, (1984) cited in Aregbeyen, (2016).

Therefore, the major concern of this study is to determine if expansionary fiscal policy will influence the performance of the Nigerian manufacturing sub-sector as its role of growth demand.

\subsection{Objectives of the Study}

The main objective of this study is to examine the impact of fiscal policy on the performance of the Nigerian manufacturing sector. Other specific objectives are:

1) To determine the impact of Company Income Tax Rate on the growth of the Nigerian manufacturing sector.

2) To examine the significance of government expenditure on the growth of the Nigerian manufacturing sector.

3) To examine the relationship existing between Federal Government Domestic Debt and Nigerian Manufacturing Sector.

4) To recommend policy options based on the results or findings of this study.

\subsection{Statement of Hypotheses}

In the course of this study, some hypotheses would be tested, which would either be validated or rejected by the result. These includes

1) $\mathrm{Ho}_{1}$ : There is no significant relationship between company income tax rate and the manufacturing sector of the Nigerian economy.

2) $\mathrm{Ho}_{2}$ : Government expenditure does not have significant impact on the growth of the manufacturing sector of the Nigerian economy.

3) $\mathrm{HO}_{3}$ : Federal Government Domestic Debt Outstanding does not have significant impact on the manufacturing sector of the Nigerian economy.

\subsection{Scope of the Study}

This study focuses primarily on Nigerian economy spanning over a period of thirty-seven years, from 1980-2017.

It exclusively deals with the fiscal policy implemented in Nigeria and structure of the manufacturing subsector throughout the period under review.

\subsection{Structure of the Study}

The study is classified into five chapters. Chapter one is the general introduction, chapter two examines the related literature on the topic.

Chapter three will show the theoretical framework and methodology, while chapter four will delve into the presentation of empirical analysis of results.

Summary, recommendations and conclusion are presented in chapter five.

\subsection{REVIEW OF RELATED LITERATURE \\ 2.1 CONCEPTUAL ISSUES}

\subsubsection{Fiscal Policy}

The term fiscal policy has conventionally been associated with the use of taxation and public expenditure to influence the level of economic activities. The implementation of fiscal policy is routed through government budget.

A budget is a projection of the flow of funds and how such funds will be spent to achieve valued objectives, which may be of individuals, households, business firms, government and institutions.

Fiscal policy is one of the basic macroeconomic phenomenon. In other to achieve macroeconomic goals 
such as full employment, price stability, sustainable growth and balance of payment, etc. which is not automatic but requires policy guidance, government has to make deliberate move through the use of fiscal and monetary policy as instrument to achieving the macroeconomic targets.

Therefore, a budget is a financial plan, which typically contains a detailed estimate of expenditures, revenues and surplus or deficits for the present and succeeding fiscal years.

Both fiscal policy and budget reflect and shape a country's economic life. In fact, the most important aspect of a public budget is its use as a tool in the management of a nation's economy (Omitogun and Ayinola, 2007).

Peter and Simeon (2011), define fiscal policy as the process of government management of the economy through the manipulation of its income and expenditure and to achieve certain desired macroeconomic objectives.

Central Bank of Nigeria (2011), defines fiscal policy as the use of government expenditure and revenue collection through tax and amount of government spending to influence the economy.

Geoff (2012) contended that fiscal policy involves the use of government spending, taxation and borrowing to affect the level and growth of aggregate demand, output and job creation. It is the government spending policies that influence macroeconomic conditions. These policies affect tax rates, interest rates and government in an effort to control the economy. Fiscal policy is the means by which a government adjusts its level of spending in order to monitor and influence a nation's economy.

Various researchers have submitted that fiscal policy goals include the following: increasing employment opportunities; attaining full employment; stabilization of domestic prices; promoting economic growth and development through industrialization; achieving stable exchange rate ; and increasing the rate of investment in the country (Anyanwu, 2004, Omitogun and Anyinola, 2007, Abeng 2009; CBN,2010 and Ogbele, Sonny and Isaac, 2011).

Sanni, (2012), sees fiscal policy as the budgetary policy of the government relating to taxes, public expenditure, public borrowing and deficit financing. Thus, fiscal policy aims at stabilizing the economy.

Again, Afam, (2012) maintained that fiscal policy is the aspect of government policy dealing with the raising of revenue through taxation and other sources and deciding on the level and pattern of expenditure for the aim of influencing economic activities.

Leslie (2018), defines fiscal policy as the means by which a government adjusts its spending level and tax rates to monitor and influence a nation's economy. It is the sister strategy to monetary policy through which a central bank influences a nation's money supply. These two policies are used in various combinations to direct a country's economic goals.

\subsubsection{The Nigerian Manufacturing Sub-Sector}

Manufacturing sector refers to those industries which are involved in the manufacturing and processing of items and indulge in either creation of new commodities or in value addition (Adebeya, 2010).

Manufacturing involves the conversion of raw material into finished consumer goods or intermediate goods.

Manufacturing can also be seen as the process of converting raw materials, components, or parts into finished goods that meet a customer's expectation or specifications. Manufacturing commonly employs a manmachine setup with division of labour in a large scale production.

According to Business Dictionary, manufacturing sector refers to agglomeration of industries engaged in chemical, mechanical, or physical transformation of materials, substances, or components into consumer or industrial goods.

Manufacturing is the business of producing goods in factories using machinery; it is generally associated with industrialization which is considered essential for rapid economic development.

Industrialization is the process of manufacturing consumer goods and capital goods and creating social overhead capital in order to produce goods and services for both individuals and business (Jhingan, 2004).

An industry connotes a number of firms producing similar goods. In the light of the foregoing, industrialization refers to the process of developing the capital of a nation and locating within its borders, the overall industrial process, involving the production of raw material, production for immediate products for further production, fabrication of the machine and tools needed for the manufacture of the desired products and of other machine skills to manage factories and to organize the production process. Industrialization thus transcends the manufacturing of consumer goods and services when generally pursued.

To Dickson (2010), manufacturing sector accounts for a significant share of the industrial sector in developed countries. The final products can either serveas finished goods for sale to customers or as intermediate goods used in the production process.

Manufacturing sector as seen by (Loto, 2012) refers to an avenue for increasing productivity in relation to import replacement and export expansion, creating foreign exchange earning capacity, raising employment and per capital income which causes unrepeatable consumption pattern.

Mbele (2012), opined that manufacturing sector is involved in the process of adding value to raw materials by turning them into products.

Thus, manufacturing industries is the key variable in an economy and motivates conversion of raw 
materials into finished goods. Manufacturing industries create employment which helps to boost agriculture and diversify the economy while helping the nation to increase its foreign exchange earnings and enabling local labour to acquire skills (Charles, 2012).

In recent times, some manufacturing industries in Nigeria have been characterized by declining productivity rate, by extension employment generation, which is caused largely by inadequate electricity supply, smuggling of foreign products into the country, trade liberalization, globalization, high exchange rate, and low government expenditure. Therefore, the slow performance of manufacturing sector in Nigeria is mainly due to massive importation of finished goods and inadequate financial support, which has resulted in the reduction in capacity utilization and input of the manufacturing sector in the economy (Tomola, Adebisi and Olawale, 2012).

Furthermore, in Nigeria, the level of growth in manufacturing sector has been affected negatively because of high interest rate on lending and this high lending rate is responsible for high cost of production in the country's manufacturing sector (Adebiyi,2001; Adebiyi and Babatope, 2004; Rasheed, 2010).

Hence, Okafor (2012) observed that the level of Nigerian manufacturing industries' performance will continue to decline because of low implementation of government budget and difficulties in accessing raw materials and stiff competition with foreign firms.

\subsection{Theoretical Literature}

Different opinions have continued to emerge on how fiscal policy can affect growth in the economy through manufacturing sector.

The origin of these controversies has been traced to the theoretical exposition of three schools of thought as enumerated by Tchokote (2001) in Omitogun and Anyinla (2007). The three schools of thought are: Classical School of thought, Keynesian school of thought and Neo- classical of thought.

Classical school of thought believes that debt issued by the public has no effect on the private sector savings.

This means that fiscal deficit financed by debt, crowds- out private sector investment and as well lower the level of economic growth and development.

Keynesian school of thought opined that there is positive relationship between deficit financing and investment. This means that fiscal policy is a tool used to overcome fluctuations in the economy.

Neo- classical school of thought challenged the position of Keynesian school of thought on the ground that the manner in which fiscal deficit $\mathrm{s}$ are financed is capable of influencing the level of consumption, investment and economic growth.

\subsection{Empirical Literature}

This section of chapter two of this work seeks to review relevant empirical studies on fiscal policy and the Nigerian manufacturing sector.

Conventionally, countries hold fiscal policy implementation in order to maintain sustainable economic activities which manufacturing sector cannot be left out.

Adenikinju and Olofin (2000) focused on the role of economic policy in the growth performance of the manufacturing sector in African countries. Their evidence indicated that government policies aimed at encouraging foreign direct investment, enhancing the external competitiveness of the economy, and maintaining macroeconomic balance have significant effect on manufacturing growth performance in Africa.

Adebiyi and Babatope-Obasa (2004) in their study on institutional framework, interest rate policy and the financing of the Nigerian manufacturing sub-sector found that interest rate spread and government deficit financing have negative impact on the growth of manufacturing sub-sector in Nigeria. In addition, they also found that rising in the index of manufacturing sub-sector is a reflection of high inflation rate and it cannot be interpreted to mean a real growth in the sector.

Omitogun and Ayinla (2007) attempt to establish whether there is a link between fiscal policy and economic growth in Nigeria using the Solow growth model estimated with the use of ordinary square method. It was found that fiscal policy has not been effective in the area of promoting sustainable economic growth in Nigeria.

That despite the increase in government expenditure, the growth rate of the economy has been very slow and sluggish. This they blame on the poor level of policy, inconsistency, high level of corruption, wasteful spending, poor policy implementation and lack of feedback mechanism for implemented policies.

This finding abolishes Keynesian theory of the need for an active policy to sustain economic growth. This is a research gap on the factors capable of hampering the effectiveness of fiscal policy.

Dickson (2007), critically examine the recent trends and pattern in Nigeria's industrial development using descriptive study. The study indicates that the level of manufacturing industry in Nigeria is concentrated in the southern and some eastern part of the country and that the spatial pattern could change if the industrialists adopt the strategy of industrial linkage.

This finding did not support any school of thought as it suggests that policy on privatization of industry in 
Nigeria should be enhanced.

Ayayi (2008) in a study of the collapse of Nigeria's manufacturing sector, used cross-sectional research design and found out that the main cause of collapse in Nigerian' manufacturing sector is low implementation of Nigeria budget, especially in area of infrastructure. This means that low implementation of fiscal policy affects the level of growth in Nigerian manufacturing sector.

Rasheed, (2010), investigated the productivity in the Nigerian manufacturing sub-sector using cointegration and an error correction model. The study indicates the presence of a long-run equilibrium relationship index for manufacturing production,determinants of productivity, economic growth, interest rate spread,bank credit to the manufacturing sub-sector, inflation rates, foreign direct investment, exchange rate and quantity of graduate employment. This finding has research gap on the area of factors that affect the manufacturing sector in Nigeria.

Ogbele, Sonny and Isaac (2011) focus on the comparative analysis of the impact of fiscal policy on economic activities in Nigeria during regulation and deregulation using the economic method of co-integration and error correction model.

The study indicates that there is a difference in the effectiveness of fiscal policy in stimulating economic growth during and after regulation.

Sangosanya (2011) used panel regression analysis model and gibrat's law of proportionate effect in investigating firm's growth dynamics in Nigerian manufacturing industry. The study observed that the manufacturing firms' finanace mix, utilization of asset to generate more sales, abundance of funds reserve and government policies are significant determinants of manufacturing industry growth in Nigeria

Charles-Ayaogu (2012) investigated the performance of monetary policy on manufacturing sector in Nigeria using econometrics test procedures. The result indicates that money supply positively affects manufacturing index performance while company lending rate, income tax rate, inflation rate, and exchange rate negatively affect the performance of manufacturing sector. This means that monetary policy is a vital tool for the growth of manufacturing sector in Nigeria which in turn would lead to economic growth. The gap in this study is that the author did not identify those factors that measure manufacturing sector performance like capacity utilization (output) and manufacturing share in GDP (input).

Loto (2012)examine the relationship between global economic meltdown and the manufacturing sector performance in the Nigerian economy using descriptive analysis pooled data. The result indicates that the global economic meltdown has insignificant effects on the manufacturing sector of the Nigerianeconomy. These empirical findings support previous literature on economic growth, but fail to use t-test or statistics in testing pre and post global economic meltdown which is research gap.

\subsection{RESEARCH METHODOLOGY}

This section is aimed at model specification and estimation method as well as the description of the material sources used in the analysis. The rest of this chapter comprises of the nature and sources of data, model specification and estimation technique.

\subsection{Nature and Sources of Data}

The data that will be generated for this study covers the period of 1980 to 2017, which is specifically secondary in nature. This is sourced from the Central Bank of Nigeria (CBN) Statistical Bulletin, Annual Report and Statement of Accounts for various years.

\subsection{Model Specification}

The empirical regression model specified below following the hypotheses stated in chapter one of this work shows the relationship between fiscal policy and the Nigerian manufacturing sub-sector.

Using the variables as defined below:

Model 1

IMS = f(GEX, CITR, FDDO.) ---------- - - (1)

Where:

IMS = Index of Manufacturing Sector

GEX $=$ Government Expenditure

CITR $=$ Company Income Tax Rate.

FDDO $=$ Federal Government Domestic Debt Outstanding.

Following hypotheses (1), this model shows the functional relationship between the index of the manufacturing sector of the Nigerian economy and fiscal policy using government expenditure, Federal Government Domestic Debt Outstanding and the inclusion of company income tax.

From equation (1) above, the linear form of the model is thus;

IMS $=\mathrm{a}_{0}+\mathrm{a}_{1}$ GEXP $+\mathrm{a}_{2}$ CITR + FDDO $+\mathrm{u}_{\mathrm{t}^{-}}--(2)$ 
This model is reasonable, to test for the impact of fiscal policy on the Nigerian manufacturing sector.

Definition and Description

IMS = Index of Manufacturing Sector.

GEX $=$ Total Government Expenditure.

CITR $=$ Company Income Tax Rate

FDDO $=$ Federal Government Domestic Debt Outstanding.

DUM = Dummy Variable for Economic Reforms.

\subsection{Estimation Technique}

Regression analysis technique will be adopted in this study, using Ordinary Least Square (OLS) method to test the performance of the variables in the model.

In addition, the relationship between the dependent and independent variables of the model will be established.

Specifically, multiple regressions will be adopted. The t test will be used to test the hypotheses as stated in the chapter one of this project work. The coefficient of determination $\left(\mathrm{R}^{2}\right)$ will also be used to test the overall performance of the model and $\mathrm{F}$ test will be used to test the overall significance of the model while the Durbin Watson (DW) test will be used to test for the presence or absence of autocorrelation in the model.

\subsection{PRESENTATION/INTERPRETATION OF REGRESSION RESULTS}

This section presents empirical regression estimates of the impact of fiscal policy on the manufacturing sector of the Nigerian economy as specified in this project.

This will follow systematically by presenting the result and interpretation of the result.

Dependent Variable: LOG(IMS)

Method: Least Squares

Date: 08/15/18 Time: 13:55

Sample: 1980-2017

Included observations: 38

\begin{tabular}{|c|c|c|c|c|}
\hline Variable & Coefficient & Std. Error & t-Statistic & Prob. \\
\hline $\mathrm{C}$ & 5.231551 & 0.250808 & 20.85881 & 0.0000 \\
\hline LOG(GEX) & 0.033633 & 0.021556 & 1.560231 & 0.1280 \\
\hline CITR & $1.10 \mathrm{E}-05$ & $7.16 \mathrm{E}-06$ & 1.529448 & 0.1354 \\
\hline LOG(FDDO) & -0.051770 & 0.021233 & -2.438196 & 0.0201 \\
\hline R-squared & 0.587737 & \multicolumn{2}{|c|}{ Mean dependent var } & 4.856011 \\
\hline Adjusted R-squared & 0.516067 & \multicolumn{2}{|c|}{ S.D. dependent var } & 0.293796 \\
\hline S.E. of regression & 0.276220 & \multicolumn{2}{|c|}{ Akaike info criterion } & 0.364065 \\
\hline Sum squared resid & 2.594120 & \multicolumn{2}{|c|}{ Schwarz criterion } & 0.536442 \\
\hline Log likelihood & -2.917229 & \multicolumn{2}{|c|}{ Hannan-Quinn criter. } & 0.425395 \\
\hline F-statistic & 2.619457 & \multicolumn{2}{|c|}{ Durbin-Watson stat } & 1.257434 \\
\hline Prob(F-statistic) & 0.046655 & & & \\
\hline
\end{tabular}

Source: Author's calculation.

The above regression suggests that the Government Expenditure LOG(GEX) and Company Income Tax Rate (CITR) have positive relationship with the Index of Manufacturing Sector LOG (IMS). While Federal Government Domestic Debt Outstanding LOG (FDDO) has negative linear relationship with the Index of Manufacturing Sector LOG (IMS).

This however implies that an increase in the LOG (GEX) and CITR by a unit is expected to increase the LOG (IMS) by 0.033633 and 1.1005 units respectively. While an increase in the LOG (FDDO) by a unit is expected to decrease the LOG(IMS) by 0.051770 units.

The $\mathrm{R}^{2}$ suggests that $58 \%$ of the total variation in the LOG (IMS) have been explained by LOG(GEX), 
LOG(FDDO) and CITR taken together. The $\mathrm{R}^{-2}$, that is the adjusted $\mathrm{R}^{2}$ for degrees of freedom agrees with the $\mathrm{R}^{2}$ since it suggests that $51 \%$ of the total variation in the LOG(IMS) has been explained by the independent or explanatory variables taken together.

The $\mathrm{F}$ test has an absolute value of (2.619457) and the probability value of $(0.046655)$ which suggests that the LOG(GEX), LOG(FDDO) and (CITR) are important factors to be taken into consideration when explaining the variations in the LOG(IMS) at 5\% level of significance.

The $\mathrm{t}$ - test at 5\% level of significance and a test of individual hypothesis also suggest that the LOG(GEX) and (CITR) with the observed value of 1.560231 and 1.529448 respectively and the respective probability values of 0.1280 and 0.1354 are statistically insignificant in explaining the changes in the LOG (IMS); while LOG (FDDO) with the observed value of $(-2.438196)$ and the probability value of 0.0201 is statistically significant in explaining the changes in LOG(IMS).

The Durbin-Watson (DW) test statistics with the observed value of (1.257434) suggests the presence of positive serial autocorrelation in the model.

\subsection{SUMMARY, RECOMMENDATIONS AND CONCLUSION 5.1 SUMMARY OF FINDINGS}

This study examined majorly the impact of fiscal policy on the manufacturing sector of the Nigerian economy which covers the period of 1980 to 2017.

From the empirical analysis carried out in this study, it was found out that fiscal policy, that is Government Expenditure and Company Income Tax do not have significant relationship with the manufacturing output, while Federal Government Domestic Debt Outstanding showed a negative and statistically significant impact on the manufacturing sector. This therefore triggered the non-performance of the manufacturing sub-sector of the Nigerian economy.

The decline of the manufacturing sub-sector could be attributed to the inherent unstable enabling environment in Nigeria. This is not unconnected with Nigeria political instability and fraudulent practices in our political system. For example, government expenditure has been increasing over the years but the actual fiscal infrastructure does not tally with the expenditure quoted. This has negative impact on the growth of the manufacturing sector.

Fiscal policy plays an important role in the development of the manufacturing sector. It determines the extent government spends money and the rate of tax charged on the productive sector of the economy.

It was found in the empirical estimation that Federal Government Domestic Debt Outstanding (FDDO) over the years, at least for the period under study (1980-2017), has a negative relationship towards the growth of the manufacturing sub-sector. This suggests that Federal Government Domestic Debt Outstanding (FDDO) has depressed the manufacturing sector. The study reviewed that fiscal policy pursued by government has not achieved its targeted aim particularly in the areas of promoting sustainable economic growth in the country.

The empirical review showed that Company Income Tax and Government Expenditure assumed a positive relationship in the model which suggests that an increase in tax rate will increase the level of manufacturing output. This is contrary to a priori expectation of the expected relationship between company income tax and manufacturing growth rate.

\subsection{Recommendations}

Based on the empirical evidences and the findings of this study, the following recommendations will be paramount to the government, researchers and students of this field of study towards the restatement of the manufacturing sub-sector of the Nigerian economy.

1) The effect of governmental and political factors exacted much influence on the performance of the manufacturing sub-sector of the economy.

Government therefore should channel her expenditure into the provision of direct physical structure that will be able to stand the competitive nature of both domestic and global market.

2) Increase in company income tax will increase the constraint or adverse structural effects on the manufacturing sector and the economy. Therefore, government should draw a policy plan that will subsidize for the manufacturing sub-sector rather than increase tax.

3) Government should also encourage the manufacturing of local resources as input in the production process of the manufacturing sector of the country. This will reduce the level of high dependency on imported factor inputs, which will also reduce the cost of production.

4) Fiscal policy may not be effective without the proper co-ordination of monetary policy.

Therefore, government should draw a policy plan that will synchronize both policies in other to stimulate the growth of the economy. 


\subsection{Conclusion}

In general, until macroeconomic policies are effectively implemented and particularly geared towards enhancing the overall productivity of the economy, the beneficial effects cannot be appreciably felt in the country.

The achievement of sustainable growth in the manufacturing sub- sector and the economy as a whole through fiscal policy in Nigeria has remained a mirage. Despite the substantial increase in government expenditure over the years, the rate of growth has been very slow and sluggish. The poor performance of fiscal policy has been ostensibly blamed on the problems of policy inconsistencies, high level of corruption, wasteful spending and poor policy implementation.

To put the manufacturing sub-sector and the Nigerian economy as a whole along the path of sustainable growth and development, the government must put a stop to the unproductive foreign borrowing, wasteful spending and uncontrolled money supply and embark upon specific policies aimed at achieving increased and sustained productivity in all the sector of the economy.

\section{REFERENCES}

Adebiyi, M.A. and Babatope-Obasa, B. (2004), Institutional Framework, Interest Rate Policy and the Financing of the Nigerian Manufacturing Sub-sector. African Development and Poverty Reduction: The Macro-Micro Linkage Forum Paper 13-15. October 2004 Lord Charles Hotel, Somerset, South Africa.

Anyanwu, J.C. (1993), Monetary Economics: Theory, Policy and and Institution. Onitsha: Hybrid Publishers Limited.

Anyanwu,J.C. and Oaikhenan, H.E. (1995), ModernMacroeconomic: Theory and Application in Nigeria. Onitsha: Jones Educational Publisher.

Bogunijoko, J.O. (2004), Growth Performance in Nigeria Empirical Evidence in the $20^{\text {th }}$ Century Leading Issue in Macroeconomic Management and Development. Ibadan: Nigerian Economic Society Daily Graphics Nigeria Limited.

CBN (2007), Central Bank of Nigeria Statistical Bulletin. Vol. 18, December.

CBN (2015) Central Bank of Nigeria Annual Report, $31^{\text {st }}$ December, 2015.

CBN (2015), Central Bank of Nigeria Statistical Bulletin

Iyoha M.A. and Itsede, C.O. (2003), Nigeria Economy:Structure, Growth and Development. Benin City: Mindex Publishing Company Ltd.

Kimberly Amadeo (2018), Fiscal Policy: Types, Objectives, and Tools. (https://www.thebalance.com/what- isfiscal-policy?)

Obi, O. Benneth (2077), "Fiscal Policy and Poverty Alleviation". Some Policy Options for Nigeria. AERC Research Paper 164. African Economic Research Consortium Nairobi ISBN 9966-778-08-X.

Omitogun Olawumi and Ayinia Tajudeen A. (2007)," Fiscal Policy and Nigerian Economic Growth" Journal of Research in Nigerian Development. Vol. 5 No. 2 December.

Risikat Oladoyin (2016), The Banking System, Manufacturing Sector and Sustainable Economic Development. A working paper. Vol. 40 No. 3 pg5. 